\title{
Entrepreneurship as a Lifestyle: The role attitude plays in the employment dynamics of workers in the fitness and children's party sectors (Córdoba, Argentina)*
}

\author{
María Inés Landa \\ CONSEJO NACIONAL DE INVESTIGACIONES CIENTIFICAS Y TÉCNICAS \\ UNIVERSIDAD NACIONAL DE CÓRDOBA \\ landa.midagmail.com \\ ORCID. 0000-0003-2668-0596 \\ Gustavo Blázquez \\ CONSEJO NACIONAL DE INVESTIGACIONES CIENTÍFICAS Y TÉCNICAS \\ UNIVERSIDAD NACIONAL DE CÓRDOBA \\ gustavoblazquez3rahotmail.com \\ ORCID. 0000-0001-7587-4982 \\ Cecilia Castro \\ CONSEJO NACIONAL DE INVESTIGACIONES CIENTÍFICAS Y TÉCNICAS \\ UNIVERSIDAD NACIONAL DE CÓRDOBA \\ cecicastro49ahotmail.com \\ ORCID. 0000-0002-0985-995X
}

Received: 16/03/2018

Accepted: 21/11/2018

\begin{abstract}
Within the framework of our research, the entrepreneur and variations on this concept emerged as a meaningful theme in the statements in interviews, and in the textual-digital material circulated in the recreation and entertainment spaces we surveyed. That is why this paper delves into the actions of the lifestyle through an analysis of the performances and practices of owners and workers in children's party venues, and in fitness gyms. The paper's introduction offers a spatial-temporal contextualisation of the political and economic scenario in which the services covered by our case studies were supplied. We go on to present some conceptual plots that we attribute to the entrepreneurial lifestyle and then proceed to examine the cultural and historical dynamics through which these businesses were set up as places for bodily well-being (gyms) and fun (children's party salons) — both things we identify as catering to Argentina's Middle Class. While our approach stresses emerging patterns linking both cases, it also highlights the special factors shaping the symbolic features of each cultural scene. The similarities and differences
\end{abstract}

\footnotetext{
* This paper was written against the background of work by one of the authors at the National Scientific and Technical Research Council and INCASI Network, a European project that has received funding from the European Union's Horizon 2020 research and innovation programme under Marie Skłodowska-Curie GA No 691004, co-ordinated by Dr. Pedro López-Roldán.
} 
found between the two cases revealed how a host of entrepreneurs (usually young people) was spawned. These youngsters need certain attitudes and creative skills to pursue their social and financial goals. Entrepreneurship as a lifestyle presupposes certain attitudes

Keywords: neo-liberal governance, subjective modulations, service-based economy, attitude, fitness gyms, children's party venues.

Corresponding author: María Inés Landa. Centro de Investigaciones y Estudios sobre Cultura y Sociedad (CIECS - CONICET and UNC). Av. Valparaíso, s/n. 5000 Ciudad Universitaria. Córdoba (Argentina).

Suggested citation: Landa, M.I., Blázquez, G. y Castro, C. (2019). Entrepreneurship as a Lifestyle: The role attitude plays in the employment dynamics of workers in the fitness and children's party sectors (Córdoba, Argentina). Debats. Journal on Culture, Power and Society, 4, 25-42. DOI: http://doi.org/10.28939/iam.debats-en.2019-3

\section{INTRODUCTION}

The accumulation model established in Argentina from the 1990s onwards opened up the country's trade and finance to international markets. "We are part of The First World", proclaimed Carlos Menem, the country's President from 1989 to $1999 .^{1}$ The 'new' model (actually an old one, given its use in the last Argentine dictatorship (1976-1983)) included: liberalisation of the Finance sector; over-valuation of the nation's currency (under the country's Ley de Convertibilidad [Convertibility Act], the Argentine Peso was pegged at one US Dollar); the sale of State Companies; the attraction of foreign capital. These policies made imported goods a lot cheaper, rendering local products less competitive and brought many Argentine industries to their knees.

To complement these changes, a legal reform programme was put into effect in the employment sphere. This made it much easier for companies to hire and fire workers, boosting the growth of multinational businesses (Pierbattisti, 2008; Del Bono, 2002).

The 'employability' construct was a key element in this process and led to a paradigm shift in ways of thinking of and regulating employment in Argentina (Pierbattisti, 2008: 34). Among other aspects, there was a move from

1 Double inverted commas are used for citations (whether translated or not) and single inverted commas for special terms or expressions. For stylistic reasons and for the sake of brevity, the masculine subsumes the feminine throughout. 'a job for life' scenario to one plagued by uncertainty, sub-contracting, and job insecurity. This sea change was the fruit of the aforementioned legal, political, and economic decisions. Symbolic and structural measures were also taken to introduce an employment model based on 'the entrepreneur' with a view to providing a flexible, profitable production system that was tried out by many companies during this period.

In addition, the application of social de-collectivisation policies, the rise in unemployment, the deterioration of working conditions, and the privatisation of public services led to growing segmentation of Argentine society (Svampa, 2005). During the 1990s, traditionally stable sectors of Argentina's Middle Class suffered unprecedented impoverishment (Minujin, 1992; Minujin and Kessler, 1995) and in the process created a new hybrid social stratum labelled by Minujin and Anguita (2004) as 'The New Poor'. Meanwhile, another sector of this transforming Middle Class was labelled 'The Innovative Middle Class', comprising those who had benefited from the political and economic changes of the period (Aguirre, 2004; Beltrán and Miguel, 2011; Svampa, 2001).

Various studies focused on new fields of meaning for part of the Middle Class, revealing the shift in the socialisation patterns of these groups based on the creation of a 'socio-spatial network' that widened the urban gap (Svampa, 2004: 61-62). Studies such as those by Svampa $(2001,2004)$ on gated communities, or 
those by Wortman (2003) on cultural consumption, showed the purchasing habits and urban practices spawned among the rising Middle Class at the time.

In this context, new consumption patterns heightened the distinctions and differentiation between the two ends of Argentina's complex Middle Class spectrum. These habits incorporated certain goods and desires, such as having money and the free time to indulge in commercialised leisure, given the contemporary, cosmopolitan image subjects wanted to build and adopt as their lifestyle. In big cities, shopping centres began to proliferate and became the new temples of mass consumption. For example, in Córdoba, a century-old State school in the city centre was bulldozed to make way for a shopping mall. Holidays abroad and shopping trips to Miami, posh parties, imported foreign cars, and luxury foreign clothes brands were all part of this new iconography of desire. "Deme dos" [Give me two!] and "Pizza y champagne" became typical expressions in these Neo-Liberal times as the $20^{\text {th }}$ Century drew to a close.

This cultural, political, judicial, and economic milieu fostered the creation and growth of a new productive sector among the Middle Class, some members of whom faced the risk of stepping down the social ladder. Spurred by the wish to keep up their standard of living, some citizens took up jobs with multinationals as low-cost skilled workers, or became self-employed (Del Bono, 2002). Some of them chose to meet the needs and demands of a small segment of society eager to pursue an active, sporting consumer lifestyle or that sought cultural experiences linked with the commercialisation of training, fun, and leisure (Aguirre, 2004; Blázquez, 2012, 2016; Castro, 2016; Duek, 2006; Landa, 2009a, 2009b, 2011a; Wortman, 2003).

The consumer heaven based on fantasies of success and happiness soon vanished in the face of the baneful effects of a model dictated by market forces, cut-throat competition and flexible employment. The 2001 politico-institutional and economic crisis and the sudden collapse of the Peso-Dollar 1:1 convertibility ushered in the economic nightmare of the 1990s (Beltrán and Miguel, 2011; Ciuffolini, 2008).
In the following years, during the presidencies of Néstor Kirchner (2003-2007) and Cristina Fernández de Kirchner (2007-2015), a form of government emerged that some authors have termed 'Neo-Developmentalist' (López and Vértiz, 2012) given its rhetorical 'inclusion' discourse. Nevertheless, as various studies have shown, apart from the few changes made, a subjective variant of Neo-Liberalism (with its stress on creativity, fun, and the entrepreneur cult) continued to operate in various iconic sections of Argentine society. ${ }^{2}$

According to Beltrán and Miguel (2011: 244), the impact of global changes, the economic situation over the last few decades, and the delicate position of the Middle Class in the 1990s were what led to the emergence of an 'entrepreneurial spirit' among creative youth working in the cultural production field. Taking research conducted in Córdoba (Blázquez, 2016; Blázquez and Castro, 2015; Castro 2016; Landa, 2011a, 2016) as our starting point, in the early 21st Century we find a burgeoning 'entrepreneurial lifestyle' that lets young Middle-Class workers join the labour market through the production of welfare and leisure services.

We shall now examine the subjective modulations of the entrepreneur role in fields affected by Neo-Liberal governance, especially those bearing on the emergence of a lifestyle combining the search for pleasure with managerialism (Bröckling, 2015). We shall then use these findings to present concepts supporting our hypotheses on how this lifestyle triggers the 'subjectification' that typifies Neo-Liberal governance (Rose, 2003: 251). ${ }^{3}$

Using this theoretical scaffold, we then analyse how the fitness and children's party sectors in Córdoba

2 Some researchers examining subjective manifestations of entrepreneurship in Argentina after 2001 include: Bayardo, 2015; Beltrán and Miguel 2011; Blázquez, 2016; Castro, 2016; Grinberg, 2009; Landa, 2011a, 2014, 2016; Landa and Marengo, 2010, 2012, 2016; Papalini, 2015.

3 Rose (2003: 251) proposes the term subjectification to denote the processes configuring certain kinds of subject. We are interested in the dynamic way that this concept foreshadows instability when the relationship between subjection and subjectivation is blurred. 
worked in the late 1980s, focusing on the activities offered. This is followed by an analysis of the differences and similarities between producers of these cultural goods, in which we detected a "virtuoso performance" (Virno, 2005) that was prized in both sectors and which those providing the services termed 'attitude'. Performance is a characteristic of this entrepreneurial lifestyle and involves workers' eagerness and cheerfulness in meeting both their clients' demands and their own. As 'transformance' (Schechner, 2000:13), attitude alters the relationship between leisure and work, and (re)produces agents capable of successfully, creatively, and cheerfully joining a service economy. Towards the end of the paper, we show that those 'producing' the services have been constrained by labour flexibility trends since the 1990s and form part of the emergence of a 21st Century entrepreneur embodying the 'spirit' of today's Capitalism. What is clear is that entrepreneurship as a 'lifestyle' requires 'attitude'.

\section{SOME CONSIDERATIONS CONCERNING SUBJECTIVE MODULATIONS OF THE PRESENT}

The consolidation of Neo-Liberal employment policies has led to subjective transformations that have redefined the repertory of aptitudes, attitudes, and skills that determine how 'the human factor' is incorporated in the production process (Dejours, 1998). The 'self-entrepreneur' as an agent who is self-made, adaptable, makes his own living, and is creative and emotionally committed to the company (which is none other than himself) has become an icon for those social groups capable of meeting the functional and financial demands made by today's organisational schema (Landa and Marengo, 2016).

Such subjectivity is discussed in the latest biopolitical theorising found in Foucault (2007), specifically when he studied the process whereby the introduction of Anarchic-Liberal governance converged with Ordoliberal rationality in Human Capital Theory. For the French philosopher, the notion that what makes us human can be seen as capital - that is, as a resource - defines life in corporate terms. This, argues Foucault, constitutes an unprecedented assault on areas that hitherto lay in the personal sphere and were thus of a 'non-economic' nature. The end result is the creation of a subjective model whereby life can be wholly governed and controlled through economic principles, reflecting the American NeoLiberal Governance notion of Homo oeconomicus as 'self-entrepreneur' (Foucault, 2007: 264-265).

Boltanski and Chiapello (2002) in their study on this 'New Spirit of Capitalism' considered that the 'networked' organisation of contemporary society, especially in the productive sphere, required both managers and workers to enshrine adaptability, change, communication, and creativity as key resources in pursuing their lives (which are seen as merely an endless stream of ever-changing projects). From the standpoint of a Fordian industrial engineer, the traits of 1950s production workers posed high risks. By contrast, the managerial model adopted by today's companies is based on the wholesale roll-out of cognitive, affective, emotional, and communicative skills that turn workers into a high-value input (Landa and Marengo, 2011).

For these authors, the cultivation of the contemporary leader must combine the savoir-faire typifying Industrial Fordism with the savoir être in which a leader is the fruit of 'individual experiences stemming from local contexts and special circumstances (Boltanski and Chiapello, 2002: 589). In this frame, worker training is not seen merely as the transfer of skills through a qualification but rather as incentives for "transferring professional know-how" through "mechanisms applicable to a host of tasks" (Dugué, 1994, in Boltanski and Chiapello, 2002: 589).

From the Latin American perspective, García Canclini and Urtezaga (2012) conducted a study on Mexico covering work organisation in the form of unstable projects as part of the creative strategies pursued by young people to enhance their economic and sociocultural advancement. Other strategies they used included: diversification of tasks and knowledge; 
participation in several projects at once; the de-institutionalisation of professional knowledge; valuing self-learning; joining in networks; use of social media (Blázquez, 2016; Jacoby, 2011).

As Foucault (1984) warned, Neo-Liberalism is an indirect style of social control, and 'guiding behaviour' whose radical innovation lies in charting a rationality of governance through the production of freedoms. At first sight, it seems contradictory - notes Gago (2014: 10) — "that this ingenious interweaving of both the personal and the institutional rests on a series of technologies, procedures, and emotions driving free initiative, self-entrepreneurship, self-management, and taking responsibility for oneself".

In fact, it is a subtle web that requires constant interfaces between the technologies of power and of the ego [in its Freudian sense], as well as the eager consent of the governed, to ensure the system's goal is achieved (Foucault, 1996). This synergetic articulation is expressed in subjective self-training processes that tie in with heterogeneous training such that "the exercise of power does not oppose the exercise of freedom" nor of obtaining pleasure (Vázquez García, 2005: 81).

Freedom, pleasure, subjectivation, and subjection all go hand-in-hand. The governance of behaviours is inextricably linked with the relationship subjects forge with themselves. This not only concerns the psychological relationship with one's inner being - something known as 'PSI practices' - but also in the way the subject establishes a specific relationship with his body as a characteristic component of the "technologies of the ego" (Foucault, 1996).

Various disciplinary fields and thematic spheres have drawn upon Michel Foucault's research on Neo-Liberal governance, acknowledging the principles and norms that make up our experience of the present (Laval and Dardot, 2013). One of the main contributors here is Nikolas Rose (1992) who, together with other British sociologists, discussed the changes in British politics under the Thatcher Government. Here, they drew on the strategy concept of 'enterprise culture'.
According to Rose (1992), this notion delimits a set of discourses, practices, and measures that are interlinked through three dimensions: Politics, Institutions, Ethics. These dimensions constitute a cultural and political programme that is forged and legitimised by fostering a regime of subjectivisation based on an idealised figure of an autonomous citizen who chooses his own lifestyle. This regime advocates managing one's own life choices through decision-making and consumption practices to maximise one's skills (and performance) and experiences (pleasure and wellbeing) in settings rife with growing competition and uncertainty (Rose, 1992). ${ }^{4}$

The figure of the 'self-entrepreneur' was fostered and legitimised as part of this process and was linked with a given lifestyle (Bröckling, 2015; Rose, 1992). The new form of subjectivisation proposed superseding the Fordist model of workers and the red tape of public institutions. It was particularly targeted at young people. Instead of the strict separation of spheres - between hobbies, cultural tastes, artistic pursuits, leisure, and work (which reflected the old scheme of things) - the entrepreneurship credo promised (and demanded) another lifestyle. The new life held out an apparently harmonious confluence of self-realisation, economic success, and a set of attitudinal requirements that would allow subjects to go forth and multiply as entrepreneurs.

Thus the new lifestyle combined diverse ethical and aesthetic regimes that were not necessarily consistent with one another but that taken as a whole, fostered plastic, consumable life which could be moulded, transferred and replicated at whim, and that were based on the 'self-entrepreneur' cult (Rose, 1992; Foucault, 2007: 264-265)

Activating the measures fostering embodiment and performance of the ideal subjectivism became a key component of production in the scheme of Neo-Liberal

4 For those who fail to adapt their behaviour to the 'entrepreneurial culture', there is expert help on hand through so-called 'therapeutic cultures (Rose, 1992). 
governance. This approach deliberately blurred the line between leisure and work to suit production and market requirements. As a result, the dichotomy between the time spent on production and on consumption was also blurred. The new 'entrepreneurs' - bombarded by discourses, best practices, and bamboozled by promises of success and personal satisfaction - actively sought to improve themselves under the unstable conditions spawned by the model (Bröckling, 2015).

We shall now describe the emergence of entrepreneurs in the fitness and children's party sectors in the city of Córdoba. The organisation of business activities bearing on fitness and on fun reveals a special relationship between leisure and work that moulds entrepreneurs' lifestyles in these sectors. We shall see how other forces also shaped the lifestyle and made up what we term attitude. These factors include: training a manageable body; affectiveness based on frustrating job satisfaction; the importance of leadership.

For this purpose, we use the empirical data gathered in two field studies in Córdoba. The first covers the observation and analysis of practices, texts and performances linked with fitness management in 2004 and 2016 (Landa, 2009a, 2009b, 2011a, 2011b, 2016). The second study used the same methodological approach and focused on the production model for children's birthday parties in the period from 2013 to 2016 (Castro, 2016). This paper draws on data culled from observations of participants and in-depth interviews with various agents - owners, managers, instructors, activity leaders, teachers, and support staff - who showed said entrepreneurial attitude and whom we contacted during the period studied.

\section{ENTREPRENEURSHIP IN THE FITNESS CULTURE}

The fitness industry reached Buenos Aires in the mid1980s and then expanded to other major cities in Argentina, such as Rosario, Córdoba, La Plata, Mar del Plata, Mendoza, and Santa Fe. The words 'aerobic' and later 'fitness' in Argentina were initially linked only with the promotion of systematic physical exercise, an athletic body, and a healthy lifestyle. The terms then became commonplace in the media, and in the services and products found in Argentine cities, adding new nuances in the process.

The formation of this new economic sector basically comprised two stages: (1) take-off; (2) consolidation, and which together were identified as "the fitness boom" (Landa, 2009a). In the first stage, local instructors learnt and incorporated the new practices, such as high-impact aerobics, body-sculpting, focused exercises, and later 'stepping'. The incorporation of these new practices and know-how occurred when some of the instructors came into contact with new gym/fitness practices in The United States or in Brazil, and through an American institute or its Brazilian representatives providing training in Argentina (Landa, 2009a, 2011a).

Those entering this new employment field had various reasons for doing so. The commonest ones were the active life style, constant travel, and being able to get a job quickly. Some of the respondents became instructors because a family member, friend, or colleague teaching physical education was already working in the sector. In other cases, they landed in the field "by chance" when outstanding students in aerobic classes were used to replace an instructor who failed to turn up. These students were then taken on by the gym as instructors.

For these youngsters, fitness became a passion, a lifestyle, a source of pleasure and opportunities, a chance to become popular and to make money. Many of these professionals, resident in Buenos Aires, travelled the length and breadth of Argentina, giving classes and attending events such as fitness congresses. These gatherings were key in forging networks and relations with trainers from other Argentine provinces or from neighbouring countries. In these gatherings, attendees pooled new know-how ("ideas and new steps"), sports apparel, film and music sequences for the daily grind in the gym, "recharging their batteries" as they made new friends who marvelled at the instructors' 'sexy bodies' as they showed off their dance routines. 
At these early stages, the pioneers gave a kick-start to the fitness industry and were the leaders in this cultural field. Tenacious, disciplined, highly aware of their body image, with strong social communication skills, pleasant and charismatic, the pioneers - many of whom considered themselves to be self-taught mobilised a large and growing number of fans. Their careers show how some youngsters who began giving gym classes in Buenos Aires (and who continued honing their skills in a well-known school) rose to the rank of director or 'trainer' in these institutions and were prized not only for their professional know-how but also for their social abilities ("how to reach people") or became part of the "star teachers" circuit. Others stood out as sportsmen in "competition aerobics", which in that period conferred distinction on those working in the field, and/or became "presenters" 5 sat national and international events in the world of fitness (Landa, 2011a: 73-76). By various routes, the instructors "who were then seen as pioneers" ended up training other instructors and in some cases were sponsored by international sports brands. In turn, some of these trainees later became master trainers themselves. ${ }^{6}$

The fitness world had consolidated by the end of the $20^{\text {th }}$ Century. In these years, new tertiary training careers were set up, such as 'group fitness instructor' and 'personal trainer', and innovations in training programmes were imported. ${ }^{7}$ The official certifica-

5 As one of the pioneer's explained: "Being a presenter addressing conferences, giving courses, and teaching other teachers" (Pionero del fitness, 20/08/2007. Buenos Aires).

6 The local history reveals two kinds of actors who left their mark on Argentina's fitness scene: (1) those who specialised in running aerobics schools and fitness events; (2) those who stood out because of their charisma and mastery of group fitness techniques. These classes bere organised through a sequence of exercises lasting an hour in all, split into segments that co-ordinated and synchronised routine training movements with the instructor "facing the mirror" and/or the students from the stage, with the students mimicking his movements, accompanied by the beat of disco-style music.

7 The training programmes in vogue at the time were spinning and indoor cycling, Body Systems, Fitness Combat classes, aerobics, and later pilates. tion of this know-how legitimised the work of the new professionals as the State regulated gym activities, quality, and infrastructure. ${ }^{\mathbf{8}}$ At that point, the management of fitness centres played a central role. ${ }^{9}$

These changes (which began in Buenos Aires shortly before the 2001 crisis and later spread to the rest of Argentina) brought innovations in gyms' management, marketing, and communication activities. These changes were reflected in the output of management texts specialising in the fitness sector, and in the holding of conferences to disseminate this knowledge (Landa, 2011a, 2011b, 2016). Another noteworthy development was the proliferation of consulting and instructional services in the 'group fitness' field, and were based on the franchise model. These measures standardised instructors' roles in the company and gave greater management control over staff.

Part of this consolidation process can be found in the adoption of a new organisational model: the "gym network". These firms were run by a management team with directors trained in accountancy and management. They aggregated various gyms, which members could choose as they pleased. The various gyms in the network forged a corporate identity through a common management model and through branding. Each venue was directed by a manager, who had two co-ordinators under him. One of the co-ordinators was trained in fitness and supervised instructors/ trainers. The other covered gym administration and accounting, and supervised the salesmen.

This organisational dynamic contrasted with the management styles of those gyms run by individuals who had been trained in Physical Education, BodyBuilding, and Fitness but who had no formal Business

8 Córdoba passed Municipal Ordinance 9938 in 1998 to regulate these business activities.

9 By management, we mean the discipline within the frame of Administration Science and Economics, whose purpose is to provide theoretical and practical know-how for managing and organising production processes in today's companies (Fernández Rodríguez, 2007). 
education. ${ }^{\mathbf{1 0}}$ The new corporate-style gyms focused on: boosting sales; hoarding currency; retaining members; broadening the services offered by the network; continued staff training. By contrast, the individually-run gyms operated on a day-to-day, hand-to-mouth basis, dealing with business instability and competition in an ad hoc fashion. The same improvisation applied in the way they dealt with unforeseen snags with buildings, regulations, tax, and gym maintenance.

Training events in the fitness management field played a big role in the adoption of the new model. An example of such an event was that held by the management team of Mercado Fitness magazine in September 2009 in a Córdoba hotel (Landa, 2011a, 2011b). This gathering was attended by international and national specialists in the gym sector and targeted managers, entrepreneurs, gym owners, and professionals in the health and fitness field. In general, such events covered matters bearing on gym management, staff management, selling subscriptions, customer retention, and corporate leadership.

According to one of the main speakers, the event was heavily attended. This speaker (who is well-known as a "fitness pioneer") is currently Regional Director of an internationally-renowned fitness company. She noted that gym owners were avid for management know-how. She said, "Many gym owners have no idea of management (...) they are teachers who one fine day set up a gym but do not have the foggiest notion of how to run a business. Guess what happened? Back in the 1980s and 90s, you could survive by muddling through. But today, if you do not learn to manage, you sink. That is why there were so many people at

10 The field work revealed how various management strategies overlapped in the Córdoba gym scene. For analytical purposes, we identify three kinds of gym. These are: (1) "networked gyms", which have already been described; (2) "neighbourhood gyms", sited in city-centre areas and occupying medium to large-premises. Their owners (trained in physical education and fitness) assumed high risks in managing the gyms; (3) "garage gyms" (mainly found on the city outskirts, with poor facilities, few students, and little demand for fitness), in which a managerial approach and innovation were conspicuous by their absence.
Mercado Fitness in Córdoba" (fitness pioneer, turned businesswoman, 10/10/2009, Buenos Aires).

The earlier gym management models proved inefficient. Words such as company, business, CEO, employee, human resources, memberships, users, customer loyalty strategies, and leadership formed the (bare) bedrock of this 'neo-language', which openly criticised the organisational forms found in the first wave of fitness and physical education businesses. The new business models proposed at the aforementioned events spread through the local scene through a semantic strategy whose purpose was none other than to replace the symbolic features of a vocational approach to running gyms (Landa, 2016).

These proposals were not uncritically accepted by the attendees and 'old hands' in the sector. An ownerinstructor in a Cordoba gym said that he had already heard of many of the proposals made at the 2009 training seminar and applied many of them, albeit in a somewhat slap-dash way. Nevertheless, the event gave him a 'method' and a way of 'systematically' applying it to labour relations.

The field work reveals that the managers of 'networked gyms' were more open to the dictates of fitness-management, while some of the owners of neighbourhood gyms lacked both the financial and/or symbolic resources to take new approaches. One of these gymowners warned that the employment situation of group fitness instructors needed to be changed before managerial ideas could be applied to running gyms. Here, he noted that such instructors "earn little and most of it is cash-in-hand".11

Despite their differences, both managers of networked gyms and owners of neighbourhood ones followed various strategies to satisfy their customers. The former did so by diversifying their facilities and services, as well as providing greater flexibility in opening hours and training spaces for members. Meanwhile, the lat-

11 "Cash in hand" denoting that these were informal jobs with no employment contract. 
ter gyms offered a laid-back, fun, family atmosphere tailored to students' needs. Whether a marketing approach or a commonsense one was taken, the aim was the same, namely to yield positive experiences that gave customers/students a sense of well-being. Positive staff/instructor attitudes were key in delivering this outcome (Landa, 2011a).

The term 'attitude' refers to the willingness of subjects to enshrine the gym or company's interests in their behaviour on the job, to satisfy changing demands, and to fully commit themselves to their work. Attitude interwove these three strands in both the narratives used by the managerial model and by the 'local gym' model. The qualities required fell into three categories: (1) personal (high self-regard, emotional and corporal self-management; (2) in relation to customers (willingness to solve problems, initiative, being helpful, sensitivity to customers' potential needs, good appearance, positive communication); (3) in relation to the organisation (being responsible, making commitments, pitching in).

The result of this process meant committing oneself body and soul to the gym's business and becoming an entrepreneur in this cultural universe. Entrepreneurial and 'self-management' subjection processes created 'subjectivation dynamics' through which some agents saw themselves as "companies, brands, entrepreneurs".

\section{THE SELF-EMPLOYED PROVIDING CHILDREN'S FUN}

Two Argentine companies pioneered products organising children's birthday parties in the mid-1980s. They were Pumper Nic, and Neverland, both operating in Córdoba. The service complemented their existing businesses. Pumper Nic specialised in fast food, while Neverland ran amusement parks. Both adapted their facilities to hold children's parties.

In the 1990s, big multinational chains "such as McDonald's and Burger King" ate away at Pumper Nic's market in Córdoba, forcing the company to close in 1995. McDonald's used advertising techniques, gaudy colours and the (re)creation of a circus atmosphere through a clown figure (Ronald McDonald) to enthral children, whom it saw as influential actors in family purchasing decisions. Furthermore, McDonald's proposed "a family atmosphere" in which adults, teenagers and children all had their own space. McDonald's birthday party service included slides and ball pits ${ }^{12}$ and coloured foam rods, "establishing a model that became hegemonic and that tended to homogenise other kinds of parties presented as alternatives" (Duek, 2006: 443). McDonald's birthday parties lasted between two and three hours, with "a common organisation of activities, presentation of the staff monitoring the activities, games in the ball pit, food, more games, and last of all, the birthday cake" (Duek, 2006: 243). This company, in addition to broadening the 'party' idea, rolled out discourses and rules on managing the service, and on labour relations stemming from the management discipline (Mangone and Reale, 2000).

These parties, outside the home and in a local commercial setting, were too expensive for some families. They were affordable for others but the novelty and allure of these parties slowly wore off. The growing demand for special ways to hold children's birthday parties led to the appearance of agents capable of satisfying this demand and coming up with new ideas. It was against this background that Middle Class families ${ }^{\mathbf{1 3}}$ discovered that organising children's party was a business that needed little up-front investment and promised easy profits.

Some of the new suppliers merely offered some of the same attractions offered by McDonalds but in a scaled-down domestic setting, through the hiring of bouncy castles, ball pits, and table football. ${ }^{\mathbf{1 4}}$ This unspecialised activity was used to supplement the household income. The items needed for the activity

\footnotetext{
12 Translator's Note: A net-enclosed area full of smallish plastic balls (too big to be swallowed) in which children run riot. Also known as ball crawl, ball pool, ball pond.

13 Middle Class (Editor)

14 Table Football (Editor).
} 
were often bought with family savings or with the severance pay of one of the family members who had been laid off. Others took advantage of the trend towards holding children's birthday parties outside the home and began offering food, beverages, and entertainment by specialised staff at an exclusive venue. The first venues for these parties were very diverse - car-parks, video clubs, pizza parlours, restaurant, paddle-ball courts, and neighbourhood stores fallen on hard times (and whose owners were keen to try new ways to make them profitable).

This commercialised form of children's birthday parties outside the home took greater hold at the turn of the century. The market grew, with the self-employed taking a slice of the business, giving this new breed of entrepreneurs a chance to thrive. Using financial surpluses from the activity and/or taking out loans, some of the self-employed "discovered the business". Yet others went one step further and "joined the fray" by either building or renting premises with the idea of using them for children's parties. ${ }^{15}$ These entrepreneurs became owners of exclusive premises or salons offering food and beverages, catering to the different tastes of children and adults. Various leisure/recreational activities were laid on and run by specialised staff or monitors in purpose-designed premises.

Market forces meant that the owners had to provide "novelty" and "variety", and meet State regulations covering the activity and the facilities offered. These regulations sought to ensure the services met certain standards. Customer satisfaction and exceeding clients' expectations held out the prospect of profitably replicating the business model, confirming the business' good name and giving it a reputation for "professionalism".

15 The trajectory of these businesses was altered at the beginning of 2005 by Ordinance 10,840, which turned them into "public entertainment", special provision being made for: "Children's Party Salons". The Córdoba Municipalities Public Entertainment Department (DEP) was charged with administering, controlling, and regulating such premises (Tamagnini and Castro, 2016).
The market "incorporated the desire and the moral obligation to hold children's birthday parties in specific ways". Those who became owners of these businesses did so based on blood relations, friendship, and/or work connections with toy company salesmen and other suppliers of the paraphernalia needed for the parties. Furthermore, such salesmen and suppliers made the entrepreneurs aware of the growing demand for children's parties, kept them in touch with the latest developments, and helped spread word of the business.

Relations with and among teachers also played a major role in the way salon owners set up business and differentiated their offerings. We note that academic training courses were particularly effective channels for forging commercial networks that led to entrepreneurial ventures. Friends and colleagues from the fields of physical education, theatre, or nursery and primary education banded together to hold children's birthday parties in suitable premises, which were often but not always State-owned. They differed from the first wave of entrepreneurs (who came from commercial fields). The second wave comprised young MiddleClass professionals keen to offer something different by drawing on their personal capital and know-how in setting up salons, which they promoted as "recreation spaces". Their pitches included the promise of turning a party into a chance to develop children's psycho-motor, cognitive, and affective skills. In addition to "fun", the service now offered the chance of "learning something".

These jobs, they said, boosted their earnings, let them manage their own timetables and "be their own bosses" yet without renouncing their artistic and/or teaching interests. Organising these children's parties was a way for these self-employed entrepreneurs to enter the job market, make ends meet, and let them work in their chosen professions. It seemed the perfect marriage between "business" and "vocation".

The management of the projects run by these youngsters was supported by various social networks. Some of them, such as family networks, were of a more longlasting nature and gave financial support, providing 
collateral against bank loans, and venues (houses, commercial premises) to hold the parties. These networks also forged an ethos based on trust, collaboration, loyalty, and the give-and-take needed to run activities and co-ordinate children's parties.

Other networks, such as the complex, varied web of acquaintances, proved less stable but no less important (Boltanski and Chiapello, 2002; García Canclini and Urtezaga, 2012). Given the flexible production model then sweeping the board, those organising children's parties used these networks to take on a variable number of staff for the occasion. Most of these employees worked without a contract or 'on the side'.

The owners' hiring policies depended on the level of interaction between employees and customers. Those who had no direct contact with customers provided support services, for example cooking and cleaning, where no special physical or communication skills were needed. In these cases, what counted was sheer hard work. By contrast, special characteristics were demanded of monitors who had direct contact with children and who had to make sure they had fun.

Here, the owners hired Middle-Class youngsters, generally under the age of 24 , and who showed dynamism, were team players, helpful and responsible. ${ }^{\mathbf{1 6}}$ Many salons used women, given that the gentler sex generally is better in dealing with children. Many had special skills, such as make-up artists - something that was highly prized in coming up with more attractive, original offerings.

The staff running parties described themselves in the same terms as their employers: 'fun people', responsible, skilled at organising creative activities, team players, good at motivating others and at delegating tasks. Most said they "loved" their work and felt great empathy toward children.

16 Most of the salons employed two entertainers for each party. Depending on the size and characteristics of each salon, the same subject would usuall run up to three birthday parties one after another.
In some cases, especially in the most commercially successful salons, the owners delegated some of their duties to workers, who played the role of "managers". This organisation allowed the owners to focus on legal and tax matters, advertising, and payroll duties. Sometimes, those owners with most capital outsourced work to specialists to perform these tasks.

The 'managers' represented the owners and dealt with the general co-ordination of the work team holding the party. They also dealt with customers and suppliers, and with starting and ending the activities. Those doing these tasks were relatives or friends of the owner or a senior monitor who had worked in the company and had shown work commitment, leadership ability, and responsibility in the job.

Monitors and managers need to be versatile in holding one children's party after another (one can think of the process as a production line). This is because they had to set the scene, receive guests, entertain the children, alter the length and intensity of the various activities, and deal with unforeseen events (such as arguments/fights). Moreover, entertaining is fast-paced, intensive work requiring a highly-organised, almost mechanical approach to the various stages of a party. The same stages are repeated over and over again for each new party. All those we interviewed said that the techniques and scripts in party salons were learnt by watching and doing. The monitors perform repertoires to elicit given responses by children. Although some 'best practices' are systematised and turned into virtual tutorials to teach new staff how to do the job, the fact is that these jobs are learnt by copying and working with others. ${ }^{17}$

Children's entertainers must control their own emotions. However tired and bored they may be, they always have to smile and be friendly when asked questions. That is because they must project happiness and a state of wellbeing at all times. Thus workers in-

17 The term "best practices", following Lugones and Tamagnini (2014), is taken to mean a set of actions that have given excellent results in a given context and from which similar future results in the same sector. 
strumentalise their emotions to maximise commercial profits $^{18}$. To the same end, they are always well turnedout. The person charged with the entertainment builds an earnest, professional façade to keep adult customers happy, while showing a more attractive, empathetic side to children. The purpose of the performances put on by these "emotion managers" (Blázquez and Castro, 2015 ) is to "spread happiness" by getting children to take their cue from the entertainer's emotional state. That is why the entertainer needs to feel what he or she is offering as a product. "If you are not having a good time, if you are not having fun, the children can tell. The key is to enjoy what you are doing", said one of the entertainers we interviewed.

Some of these youngsters have instrumental relations with the salons. They try to pursue other professional paths, such as music, psychology, theatre, or physical education and the job lets them put their knowledge into practice, gain some experience, and earn money to put towards their university studies. Other youngsters, with less schooling are more interested in the commercial side and stay in the children's entertainment market with the aim of becoming managers or of setting up their own business. For the first group of youngsters, working as entertainers in children's party sector is a fleeting stage that helps them put their knowledge into practice and to make some money on the side. For these respondents, it was merely a project for gaining professional and personal experience that could later be turned to good use in other projects. For the second group, the activity offered the chance of learning a trade and later of setting up a business to become entrepreneurs.

Going beyond the projects and goals of the owners, managers, and entertainers, workers' production of children's parties demanded the same attributes (relationships with themselves, with clients, and with entrepreneurship) as we found in the fitness sector. In both fields, great store was set by: (self-) leadership;

18 Hochschild (1983) used the term "emotional work" to denote a wide range of service jobs that require workers to manipulate their emotions to meet their employer's requirements. initiative; a 'can do' willingness to trouble-shoot; the ability to "roll up one's sleeves". Both cases reveal how in committing themselves to the company's goals, whether in the case of gyms or the party salons, subjects became "self-entrepreneurs" who turned their own subjectivity into a resource and were responsible for managing both their bodies and their emotions.

\section{SOME DIFFERENCES AND THE SAME 'ATTITUDE'}

As we saw, there was a boom in the coverage of fitness in the Argentine media in the 1980s and the new activity was spread through the practices of instructors, trainers, and pioneers who set up commercial projects and neighbourhood gyms. Decades later, the activity took the form of a thriving industry, spurred on by the fitness-management discourse and the forging of macro business organisations, such as networked clubs.

In the same period, there was a boom in children's party venues. In this case, the process followed the reverse path (that is, from macro to micro scale). The party services emerged as a complementary but distinctive service in amusement parks and in fast-food chains. As time wore on, families and youngsters jumped on the bandwagon to join an entrepreneurial Middle Class, carving out a market niche solely focusing on children's entertainment and in the process, greatly boosting the supply of such services.

State authorities drew up regulations covering activities, and premises in these booming sectors. A section on public entertainment was added to cover children's parties. A special ordinance was drawn up for gyms, regulating their activities at the local level.

State intervention created a legal framework covering the development of these businesses as 'safe establishments', legitimising them in the public's eyes. During this regulation, not all owners had the means to bring their premises up to the standards required by Law.

In addition to setting legal requirements, these ordinances required special actors. In the case of gyms, 
a physical education instructor had to supervise all activities. In the case of venues for children's parties, there had to be one adult supervisor for every ten children. In both cases, owners complied with the letter of the Law (but not always its spirit) by adapting staff tasks to meet statutory requirements.

Legalisation of businesses led to steady 'professionalisation' of these sectors through the incorporation and creation of semantic and digital know-how and technology. Such measures stemmed from agents working in these cultural contexts. They contributed experience and innovation to boost the efficiency of self-management. In doing so, these agents differentiated themselves in the labour market and boosted the profitability of these businesses.

In the case of fitness, this process led to gradual 'formalisation' of the sector. As the industry grew and its organisational processes became more complex, so too did the need for new knowledge, actors, and working methods. The application of management disciplines to fitness enshrined "the future of the profession", conveying the need for business methods and accounting technologies to run gyms. The management of fitness, among other things, brought new actors (such as sales and service managers) and models (fitness entrepreneurs), who competed with the pioneers' vocational culture.

By contrast, the boom in children's party salons produced a trend towards greater formalisation in this sector. This was reflected in the outsourcing of specialists for administration, the delegation of tasks (co-ordination, team management, and client service), which some owners designated as 'staff managers', and the incorporation of franchise systems for local businesses.

Despite the differences between the two sectors, one can recognise the same 'virtuoso performance' among workers - something that boiled down to 'attitude'. The term meant both everything and nothing and was thus ideal for the symbolic-instrumental order found in gyms and in party salons. "Having the right attitude" meant being and appearing to be an entrepreneurial subject, being helpful, aware of one's setting, and having a pleasant, seductive manner. It also meant quickly adapting to the flexible management approach found in both fields, to the instability in the local market, and to pulling through successive economic crises at the national level.

This 'attitude' took different forms depending on agents' functions, roles, and positions in these work settings. Owners (in both party salons and gyms), the managers of gym networks, and entrepreneurs were turned into 'personal brands'. Here, one can see a set of specific measures, such as the permanent quest for opportunities and the drawing up of differentiation strategies (both for themselves and for their businesses) to enhance the service offered and its profitability. For these subjects, their "entrepreneurial attitude" was what made the creation and realisation of their projects possible, while their "leadership ability" forged trust and loyalty between their staff and their customers.

These 'self-made' approaches were broadened to include "human resources" in the company, premises, or business. As we noted earlier, entertainers at children's parties and group fitness instructors had to embody a set of social, communication, corporal, and emotional skills, depending on what was needed by each business venture. Workers' subjective involvement in the commercial venture and their service orientation were seen as key to the business' success. This is because these factors had a big impact on product quality and on customer satisfaction. This "attitude" was also important in these subjects' professional career and continued employment. Success, staff, and the company were all rooted in workers' commitment to their tasks and job, the extent to which they identified with what they did, and the adoption of an entrepreneurial lifestyle. They managed and showed this commitment through the overall cultivation of their lives. In pursuing the desired attributes (joy, will, discipline, rhythm, dynamism), they had to transfer these to: others willing to actively consume their services; the workers they managed; the most delicate and intimate of interfaces - their bodies and their 
emotions. ${ }^{19}$ In an idealised manner, entrepreneurs in gyms and children's parties had to turn themselves into paragons of the subjectivities they were proffering.

As part of this process, the dual perception of time characterising Fordist Capitalism was diluted and with it, the distinctions between work/leisure and production/consumption were blurred. Turning hobbies into entrepreneurial ventures and shifting from amateurs to professionals fostered an entrepreneurial lifestyle in which subjects "with attitude" were always willing to provide a service and permanently train for their next task.

In this scheme of things, leadership becomes the "art of managing bodies" to meet measurable production goals (Abraham, 2000: 35), while social life turns into a "managerial crusade" in which the figure of the entrepreneur appears as the stereotypical hero. The new lifestyle urges each subject to become his own leader. "Attitude" implies that to exercise leadership, the subject must first learn to manage himself if he is to seduce and manage others (customers, students, staff). ${ }^{20}$

As we saw, through various paths, subjects turn themselves into a company, a "brand" that they seek to position in the market (and not just the job market). As part of this process, the inner man is turned into outer appearance, all thanks to the lightning-fast spread of information through social networks (Facebook, Twitter, Instagram). Under this new order, the production of capital does not merely depend on selling one's labour. Today's Capitalism also exploits human beings' capacity for excitement or potentia gaudendi (Preciado, 2014: 41). Instead of ditching The Protestant Work Ethic, the "New Spirit of Capitalism" incorporates and

19 For example, fitness instructors and entertainers must manage ill humour, tiredness, and muscle pains to convey joy and get participants to move, dance, and train. They also resort to 'sports drinks' to keep active and prevent dehydration.

20 Here, one should note that following Foucault (2009: 309), the ability to govern the external world supposes that one can first govern oneself. expands it following the "Weber-Hilton Principle" (Preciado, 2014: 212-214). The serial (and serialised) sinning of young people such as Paris Hilton or the Kardashian sisters does not hide rejection of Capitalism and Puritan ethics but rather shows their willingness to throw body and soul into becoming sex symbols for gain, and - through web cams, CCTV cameras and the like - to turn themselves into a globally transferable image. It is not hedonism and the seeking of worldly pleasures that orients consumerism but rather ruthless management of the excitationfrustration switch. The entrepreneurs in the fitness and children's party fields know that such management demands the whole-hearted participation of workers in job practices and, ideally, their sublimation in the 'flow experience' (Csikszentmihalyi, 1993). "Attitude" as "virtuous performance" reveals this demand. For example, instructors turn themselves into their own brand and company through their image (spread through audiovisual networks and media), portraying a healthy, active lifestyle that requires endless, painstaking cultivation of one's physical appearance. Such cultivation demands punishing daily routines, personal care and aesthetics that form part of the lives and lifestyles of these subjects. The owners of party salons spread contents bearing on children and family life, highlighting messages from customers thanking entertainers for their work.

\section{FINAL CONSIDERATIONS}

Within the framework of our research, the cult of the entrepreneur and its various manifestations are revealed in the statements made by those interviewed and in the textual-digital material circulated in the leisure and entertainment sectors studied. That is why this paper delved into the dynamics of the lifestyle through analysis of the performances and practices of owners and workers in both the children's party scene and in fitness gyms.

The introduction gave a spatial and temporal contextualisation of the politico-economic stage on which the services covered in our case study were developed. We 
then went on to examine: (1) the conceptual strands making up the entrepreneurial lifestyle; (2) the cultural and historic dynamics creating these industries selling fitness and fun to Argentina's Middle Class.

The focus highlighted the similarities in both cases but we also noted the differences. By observing both, we saw how an army of ordinary virtuoso entrepreneurs was created. These entrepreneurs were generally young, had to have 'attitude', and harnessed their creativity to cultivate a lifestyle to reproduce their socio-economic model. Despite the enthusiasm of these entrepreneurs, certain employment conditions hindered their unconditional commitment to their jobs. The obstacles were: sub-contracting/outsourcing and job insecurity; the scant recognition they got for their efforts; the long hours worked; informal employment without a contract. Such conditions led to loss of motivation and weariness, which were penalised by their employers. Even so, these agents of the fun and fitness sectors felt forced to look for other jobs and projects that would allow them to enhance both their quality of life and standard of living. The new entrepreneurial cult (reflected in the fact that some agents described themselves as entrepreneurs) led to more self-governance (tending to foster hegemony) in the production of the subjectivities implied in the formation of a "New Spirit of Capitalism".

\section{BIBLIOGRAPHIC REFERENCES}

Abraham, T. (2000). La empresa del vivir. Buenos Aires: Sudamericana.

Aguirre, P. (2004). Seguridad Alimentaria. Una visión desde la antropología alimentaria, in Desarrollo integral en la infancia: el futuro comprometido. Córdoba (Argentina): Fundación CLACYD, s.p., www.suteba.org.ar/ download/da-de-la-alimentacin-el-hambre-es-un-crimen-mundial-8333.pdf (accessed on 18th April 2017).

Bayardo, R. (2015). Anegados de la cultura: «Be Creative!». In L. A. Quevedo (comp.), La cultura argentina hoy. ¡Tendencias! (pp. 255-285). Buenos Aires: Siglo Veintiuno.

Beltrán, G. and Miguel, P. (2011). Emprendedores creativos. Reacomodamientos en trayectorias de la clase media por la vía de la inversión simbólica, in L. Rubinich and P. Miguel (eds.), Creatividad, economía, cultura en la ciudad de Buenos Aires (225-253). Buenos Aires: Aurelia Rivera.

Blázquez, G. (2012). I love the nightlife. Música, imágenes y mundos culturales juveniles en Argentina. Trans: Revista Transcultural de Música, 16, 1-26.

Blázquez, G. (2016). Hacer la noche. La producción comercial y el mercado laboral de los clubes electrónicos. Trabajo y Sociedad, 27. www.unse.edu.ar/trabajoysociedad/27\%20BLAZQUEZ\%20GUSTAVO\%20TrabajoySociedad. pdf (accessed 10th June 2017).

Blázquez, G. and Castro, C. (2015). ¡Los quiero bien arriba! Gestión de emociones en eventos festivos. Actas XI Jornadas de Sociología. Facultad de Ciencias Sociales. Buenos Aires: Universidad de Buenos Aires. http://cdsa. aacademica.org/000-061/182.pdf (accessed 15th June 2017).

Boltanski, L. and Chiapello, E. (2002). El nuevo espíritu del capitalismo. Madrid: Akal.

Bröckling, U. (2015). El self emprendedor. Sociología de una forma de subjetivación. Santiago de Chile: Universidad Alberto Hurtado.

Castro, C. (2016). Feliz en tu día. Una etnografía sobre fiestas de cumpleaños infantiles en espacios mercantilizados, Gustavo Blázquez (dir.). Córdoba: Universidad Nacional de Córdoba.

Ciuffolini, M.A. (2008). Resistencia y Conflicto: Luchas Sociales Urbanas en Córdoba Post-2001, Adrián Scribano (dir). Buenos Aires: Universidad de Buenos Aires.

Csikszentmihalyi, M. (1993). The evolving self. Nueva York: Harper Collins.

Del Bono, A. (2002). Telefónica. Trabajo degradado en la era de la información. Madrid: Miño y Dávila editores.

Dejours, C. (1998). El factor humano. Buenos Aires: Lumen-Hvmanitas. 
Duek, C. (2006). Infancia, fast-food y consumo, o cómo ser niño en el mundo McDonald's, in S. Carli (compilation). La cuestión de la infancia. Entre la escuela, la calle y el shopping (pp. 241-264). Buenos Aires: Paidós.

Fernández Rodríguez, C. (2007). El discurso del management: tiempo y narración. Madrid: Centro de Investigaciones Sociológicas.

Foucault, M. (1984). Space, Knowledge, and Power. In P. Rabinow (comp.). The Foucault Reader (pp. 239-256). Nueva York: Pantheon Books.

Foucault, M. (1996). Tecnologías del yo y otros textos afines. Barcelona: Paidós-Instituto de Educación de la Universidad Autónoma de Barcelona.

Foucault, M. (2007). El nacimiento de la biopolítica. Buenos Aires: Fondo de Cultura Económica.

Foucault, M. (2009). El gobierno de sí y de los otros. Buenos Aires: Fondo de Cultura Económica.

Gago, V. (2014). La razón neoliberal. Economías barrocas y pragmática popular. Buenos Aires: Tinta Limón.

García Canclini, N. and Urteaga, M. (co-ordinators.) (2012). Cultura y desarrollo. Una visión crítica desde los jóvenes. Barcelona: Paidós

Grinberg, S. (2009). Tecnologías del gobierno de sí en la era del gerenciamiento: la autoayuda entre el narcisismo y la abyección. Psicoperspectivas, VIII(2), 293-308.

Hochschild, A. (1983). The Managed Heart: Commercialization of Human Feeling. New York: University of California Press.

Jacoby, R. (2011). El deseo nace del derrumbe: acciones, conceptos, escritos. Barcelona: Ediciones de la Central.

Landa, M. (2009a). El porvenir de los cuerpos rentables: un análisis de la práctica del fitness. In R. Crisorio and M. Giles (eds.), Educación física. Estudios críticos de educación física (pp.177-192). La Plata: Al Margen.

Landa, M. (2009b). Subjetividades y consumos corporales: un análisis de la práctica del fitness en España y Argentina. Razón y Palabra, 69. En www.razonypalabra.org.mx/SUBJETIVIDADES\%20Y\%20CONSUMOS\%20 CORPORALES\%20UN\%20ANALISIS\%20DE\%20LAS\%20PRACTICAS\%20DEL\%20FITNESS\%20EN\%20 ESPANA\%20Y\%20ARGENTINA\%20.pdf (accessed 10th June 2017).

Landa, M. (2011a). Las tramas culturales del «fitness»: los cuerpos activos del ethos empresarial emergente, Meri Torras (dir.). Barcelona: Universidad Autónoma. In www.tdx.cat/bitstream/handle/10803/42294/mil1de3. pdf?sequence $=1$ (accessed 16th September 2016).

Landa, M. (2011b). «Cultura» en las tramas empresariales del fitness en Argentina. La explotación de un concepto. La Piel en la Palestra. Estudios Corporales, II (pp. 393-402). Barcelona: Universitat Oberta de Catalunya.

Landa, M. (2014). La sonrisa del éxito: figuraciones de una subjetividad exigida, Arxius de sociología, 30, $153-168$.

Landa, M. (2016). Fitness-management: el conflictivo devenir de una cultura empresarial. Revista Brasileira de Ciencias do Esporte, 38(1), 18-25.

Landa, M. and Marengo, L. (2010). Devenir cuerpo empresa: el nuevo capitalismo y sus tramas de sujeción. Cuerpos contemporáneos: nuevas prácticas, antiguos retos, otras pasiones, Dossier Actuel Marx/Intervenciones, 9, 161-182.

Landa, M. and Marengo, L. (2011). El cuerpo del trabajo en el capitalismo flexible: lógicas empresariales de gestión de energías y emociones. Cuadernos de Relaciones Laborales, 29(1), 177-199.

Landa, M. and Marengo, L. (2012). La di-gestión de energías en los call centers: entre cuerpos des-hechos y performances del liderazgo. Trabajo y Sociedad, 18(XV). www.unse.edu.ar/trabajoysociedad/18\%20 LANDA_MARENGO\%20Call\%20Centers (accessed 10th June 2017).

Landa, M. and Marengo, L. (2016). El sí mismo como empresa: sus operatorias y performances en el escenario managerial (pp. 24-50). In N. B. Rodríguez and H. Viafara Sandoval (comps.), Michel Foucault, treinta años después. Aportes para pensar el problema del cuerpo y la educación. La Plata: Universidad Nacional de La Plata; Cali: Universidad de San Buenaventura Cali.

Laval, C. and Dardot, P. (2013). La nueva razón del mundo. Ensayo sobre la sociedad neoliberal. Barcelona: Gedisa.

López, E. and Vértiz, F. (2012). Capital transnacional y proyectos nacionales de desarrollo en América Latina. Las nuevas lógicas del extractivismo neodesarrollista. Herramienta, 50, 21-36. 
Lugones, M. G. and Tamagnini, M. L. (2014). Implantaciones de la fórmula «buenas prácticas» en la Córdoba del siglo XXI. Proyecto Tipo A, Convocatoria de Subsidios a Proyectos de Investigación 2012-2013, Secretaría de Ciencia y Técnica. Córdoba: Universidad Nacional.

Mangone, C. and Reale, A. (2000). Acercamiento semiótico-discursivo a McDonald's. Entre la globalización semiótica y la semítica de la globalización. Razón y revolución, 6(1), 20-27.

Minujin, A. (ed.) (1992). Cuesta Abajo. Los nuevos pobres: efectos de la crisis en la sociedad argentina. Buenos Aires: UNICEF-Losada.

Minujin, A. and Anguita, E. (2004). La clase media. Seducida y abandonada. Buenos Aires: Edhasa.

Minujin, A. and Kessler G. (1995). La nueva pobreza en la Argentina. Buenos Aires: Temas de Hoy-Planeta.

Papalini, V. (2015). Garantías de felicidad. Estudios sobre los libros de autoayuda. Buenos Aires: Adriana Hidalgo.

Pierbattisti, D. (2008). La privatización de los cuerpos. La construcción de la proactividad neoliberal en el ámbito de las telecomunicaciones, 1991-2001. Buenos Aires: Prometeo Libros.

Preciado, B. (2014). Testo Yonqui. Sexo, drogas y biopolítica. Buenos Aires: Paidós.

Rose, N. (1992). Governing the Enterprising Self. In P. Heelas and P. Morris (eds.), The Values of the Enterprise Culture: The Moral Debate (pp.141-164). Londres: Routledge.

Rose, N. (2003). Identidad, genealogía e historia. In S. Hall and P. du Gay (eds.), Cuestiones de identidad cultural (pp. 214-250). Buenos Aires: Amorrortu.

Schechner, R. (2000). Performance. Teoría y prácticas interculturales. Buenos Aires: Libros del Rojas-Universidad de Buenos Aires.

Svampa, M. (2001). Los que ganaron. La vida en los countries y en los barrios privados. Buenos Aires: Biblos.

Svampa, M. (2004). La brecha urbana. Buenos Aires: Clave para Todos.

Svampa, M. (2005). La sociedad excluyente. La Argentina bajo el signo del neoliberalismo. Buenos Aires: Taurus.

Tamagnini, L. and Castro, C. (2016). Una aproximación etnográfica a las actuaciones administrativas para la gestión municipal de la diversión en Córdoba. Revista Astrolabio. Nueva Época, 16(1), 362-389.

Vázquez García, F. (2005). Empresarios de nosotros mismos. Biopolítica, mercado y soberanía en la gubernamentabilidad neoliberal. In J. Ugarte Pérez (comp.), La administración de la vida (pp. 73-103). Barcelona: Anthropos.

Virno P. (2005). Cuando el verbo se hace carne. Madrid: Traficantes de Sueños.

Wortman, A. (2003). Pensar las clases medias. Consumos culturales y estilos de vida urbanos en la Argentina de los noventa. Buenos Aires: La Crujía

\section{BIOGRAPHICAL NOTE}

\section{María Inés Landa}

PhD in The Theory of Literature and Comparative Literature from Universidad Autónoma de Barcelona (UAB). Researcher at Centro de Investigaciones y Estudios sobre Cultura y Sociedad [Centre for Research and Studies on Culture and Society] (CONICET and UNC) and professor at Universidad Nacional de Córdoba and Universidad Católica de Córdoba. She studies practices and artifacts in which the body is the subject of management, negotiations, and diverse appropriations.

\section{Gustavo Blázquez}

PhD in Anthropology from Universidad Federal de Río de Janeiro. Professor of the Philosophy and Humanities Faculty of Universidad Nacional de Córdoba and researcher at Instituto de Humanidades [Institute of Humanities] (CONICET). He researches the production of feelings and subjectivities from analysis of performances bearing on urban youth cultures, nighttime cultural consumption and sexuality. 


\section{Cecilia Castro}

Master's Degee in Anthropology and Degree in Social Communication from Universidad Nacional de Córdoba (UNC). She is currently taking a PhD in Anthropological Sciences (FFyH-UNC). She is a scholarship student at Consejo Nacional de Investigaciones Científicas y Técnicas [National Council for Scientific and Technical Research] and works in the Instituto de Humanidades [Institute of Humanities] (IDH). Her work focuses on ethnographic analysis of children's cultural consumption and the production of subjectivities. 